Open Access

\title{
Expression of adiponectin, chemerin and visfatin in plasma and different tissues during a laying season in turkeys
}

Mélodie Diot 1,2,3,4, Maxime Reverchon ${ }^{1,2,3,4}$, Christelle Rame ${ }^{1,2,3,4}$, Pascal Froment ${ }^{1,2,3,4}$, Jean-Pierre Brillard ${ }^{5}$, Sylvain Brière ${ }^{6}$, Gérard Levêque ${ }^{6}$, Daniel Guillaume $e^{1,2,3,4}$ and Joëlle Dupont ${ }^{1,2,3,4^{*}}$

\begin{abstract}
Background: In mammals, adipose tissue is able to secrete various hormones called adipokines including adiponectin (ADP), chemerin (Chem) and visfatin (Visf) which are involved in controlling energy metabolism as well as reproductive functions. Visf receptor is still unknown whereas ADP and Chem mainly act through AdipoR1, AdipoR2 and CMKLR1 and GPR1 receptors, respectively. No studies have yet demonstrated the presence of these three adipokines in peripheral tissues, ovarian cells or turkey plasma. Here, we investigated the expression (mRNA and protein) of ADP, Chem, Visf and their receptors in peripheral tissues and ovarian cells (granulosa and theca cells) from hierarchical follicles. Furthermore, we determined the plasma profile of ADP, Visf and Chem at different physiological stages: start, peak and end of the laying period in Meleagris gallopavo turkeys. This data was correlated with the metabolic data (plasma glucose, triglycerides, cholesterol and phospholipids).

Methods: Tissue and ovarian cells mRNA and protein expression levels were determined by RT-qPCR and immunoblot, respectively. Plasma adipokines were measured by chicken ELISA and immunoblotting.

Results: In turkeys, Chem is mainly expressed in the liver while ADP and Visf are mainly expressed in the abdominal adipose tissue and pectoral muscles,respectively. As in mammals, AdipoR1 and AdipoR2 expression levels (mRNA and protein) are highly present in muscle and liver, respectively, whereas the mRNA expression of CMKLR1 and GPR1 is ubiquitous. In ovarian cells, ADP, Visf, Chem and their receptors are more highly expressed in theca cells than in granulosa cells excepted for AdipoR1. Furthermore, we found that plasma levels of ADP, Chem and Visf were reduced at the end of the laying period compared to the start of this period. At the plasma levels, the levels of these adipokines are strongly negatively correlated with glucose and only plasma Chem is negatively correlated with cholesterol, triglycerides and phospholipids.
\end{abstract}

Conclusions: In turkeys, ADP, Visf and Chem and their receptors are expressed in peripheral tissues and ovarian cells. Plasma concentration of ADP, Visf and Chem decrease at the end of laying period and only plasma Chem is negatively correlated with levels of cholesterol, triglycerides and phospholipids levels during the entire laying period.

Keywords: Turkey, Adipokine, Laying season

\footnotetext{
* Correspondence: jdupont@tours.inra.fr

'INRA, UMR85, Unité Physiologie de la Reproduction et des Comportements, Nouzilly F-37380, France

${ }^{2}$ CNRS, UMR6175, Nouzilly F-37380, France

Full list of author information is available at the end of the article
}

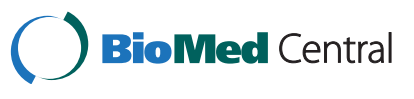

(c) 2015 Diot et al. This is an Open Access article distributed under the terms of the Creative Commons Attribution License (http://creativecommons.org/licenses/by/4.0), which permits unrestricted use, distribution, and reproduction in any medium, provided the original work is properly credited. The Creative Commons Public Domain Dedication waiver (http:// creativecommons.org/publicdomain/zero/1.0/) applies to the data made available in this article, unless otherwise stated. 


\section{Background}

In mammals, adiponectin (ADP), visfatin (Visf) and chemerin (Chem) are adipokines produced and secreted by white adipose tissue. They regulate glucose and energy metabolism [1] as well as reproduction including gonad steroidogenesis [2] and gonadotropin secretion [3, 4]. Adiponectin, one of the most studied adipokines, circulates in the form of homo-multimers [5] and its impact is mainly via binding to the AdipoR1 and AdipoR2 receptors [6]. Chem, or RARRES2, is a new adipokine that is involved in the regulation of adipogenesis, energy metabolism, and inflammation [7]. Chemokine-like receptor 1 (CMKLR1), also called ChemR23, GPR1 (G protein-coupled receptor 1) and chemokine (C-C motif) receptor-like 2 (CCRL2) are G-protein-coupled receptors known to bind Chem [8]. Visf is both a systemic adipokine and the cytosolic enzyme, nicotinamide phosphoribosyl transferase (Nampt) that is involved in metabolic (obesity, type II diabetes) and immune disorders [9]. In constrat to ADP and Chem, no Visf receptor has yet been identified.

Chicken exhibits particular features for glucose metabolism. For example, despite the presence of insulin circulating at "normal" concentrations, chickens present a high level of glycaemia, and low sensitivity to exogenous insulin [10-12]. In chickens, while ADP and its receptors and Visf have already been studied in plasma and different tissues $[13,14]$, Chem and its receptors have never been examined. In chicken plasma and tissues, ADP is predominantly a high molecular weight multimer [15]. Moreover, as in mammals, ADP is largely expressed in chicken adipose tissue [13, 16] and gonads [17]. ADP receptors, AdipoR1 and AdipoR2 are also expressed in different peripheral and reproductive tissues $[18,13]$. As opposed to mammals, Visf is more highly expressed in muscle than in adipose tissue in chickens [19]. Consequently, Visf is described as a myokine and not an adipokine in chickens. In the latter species, the full-lentgh cDNA of Visf gene has been cloned and sequenced [20]. It shares a high amino acid sequence identity not only with the Visf of human but also fish. The chicken Visf gene expression is sex and tissue dependent. Indeed females have a higher amount of Visf mRNA in adipose tissue compared to males [21]. Moreover, Visf is expressed in gonads [14, 22] where it could play an important role in steroidogenesis, spermatogenesis and folliculogenesis [14]. Although ADP and Visf have been characterized in chickens, no data is available about the plasma concentration of these adipokines during the laying period in poultry.

In this study, we investigate the expression of these adipokines in peripheral tissues and ovarian cells and their plasma concentration in turkeys. Firstly, we studied the mRNA and protein expression of ADP, Chem, Visf and their receptors in peripheral tissues (adipose tissue, liver, pectoral and leg muscle and the heart) and ovarian cells (granulosa and theca cells) from hierarchical follicles. Secondly, we determined the plasma profile of ADP, Visf and Chem at different physiological stages: start, peak and end of laying period in Meleagris gallopavo turkeys (heavy strain Converter). Last but not least, this data was correlated with metabolic data (plasma glucose, triglycerides, cholesterol and phospholipids).

\section{Methods \\ Animals}

Eighty-eight Meleagris gallopavo turkeys (heavy strain Converter) from a commercial breeding unit of Hendrix Genetics (Saint Laurent de la Plaine, France) were studied at three different stages of a laying season: start (32 week-old), peak (35 week-old) and end (55 weekold). Animals were housed together with free access to feed and water and were exposed to a $15 \mathrm{~h}$ light:9 $\mathrm{h}$ darkness photoperiod. The diet nutritional composition was: Metabolisable Energy $(2999 \mathrm{kcal} / \mathrm{kg}$ ), crude protein (17\%), lysine (0.97\%), methionine (0.45\%), calcium (2.9\%), phosphorus $(0.45 \%)$. At the start, peak and end of the laying period, each fasted animal was weighted and a blood sample was taken. Blood samples were immediately centrifuged at $1,000 \times \mathrm{g} 15 \mathrm{~min}$ at $4{ }^{\circ} \mathrm{C}$ to obtain plasma that was then stored at $-20{ }^{\circ} \mathrm{C}$ until use. The weight of animals was significantly decreased at the peak or at the end as compared to the start laying period (Table 1). At the end of laying period, six animals were sacrificed by electronarcosis and exsanguination and tissues (abdominal adipose tissue (AT), liver, heart, skeletal and pectoral muscles and ovarian hierarchical follicles) were collected and frozen at $-70{ }^{\circ} \mathrm{C}$ until use. Granulosa (GC) and theca (TC) cells from F1 and F3/4 hierarchical follicles were dissected and also frozen at $-70{ }^{\circ} \mathrm{C}$. The experiment was carried out in accordance with French and European regulations on the care and welfare of animals in research. All procedures were approved by the Agricultural and Scientific Research Government Committee in accordance with the guidelines for the Care and Use of Agricultural Animals in Agricultural Research and Teaching (approval A37801).

Table 1 Body weight, plasma levels of glucose, cholesterol, triglycerides and phospholipids of turkeys $(n=88)$ at different periods of laying (start, peak and end)

\begin{tabular}{llll}
\hline & Start $(\mathrm{n}=88)$ & Peak $(\mathrm{n}=88)$ & End $(\mathrm{n}=88)$ \\
\hline Body Weight $(\mathrm{kg})$ & $12.462 \pm 0.083^{\mathrm{a}}$ & $12.176 \pm 0.084^{\mathrm{b}}$ & $12.009 \pm 0.093^{\mathrm{b}}$ \\
Glucose $(\mathrm{g} / \mathrm{L})$ & $1.991 \pm 0.015^{\mathrm{a}}$ & $2.249 \pm 0.032^{\mathrm{b}}$ & $2.541 \pm 0.048^{\mathrm{c}}$ \\
Cholesterol $(\mathrm{g} / \mathrm{L})$ & $1.702 \pm 0.059^{\mathrm{a}}$ & $1.801 \pm 0.067^{\mathrm{a}}$ & $1.890 \pm 0.091^{\mathrm{a}}$ \\
Triglycerides $(\mathrm{g} / \mathrm{L})$ & $15.086 \pm 0.553^{\mathrm{a}}$ & $16.383 \pm 0.648^{\mathrm{a}}$ & $11.380 \pm 0.560^{\mathrm{b}}$ \\
Phospholipids $(\mathrm{g} / \mathrm{L})$ & $5.235 \pm 0.553^{\mathrm{a}}$ & $4.919 \pm 0.134^{\mathrm{ab}}$ & $4.601 \pm 0.132^{\mathrm{b}}$ \\
\hline
\end{tabular}

Different superscript letters indicate significant differences at $p<0.05$ 


\section{Plasma biochemical parameters}

The levels of plasma total cholesterol $(\mathrm{g} / \mathrm{L})$, triglycerides $(\mathrm{g} / \mathrm{L})$ and phospholipids $(\mathrm{g} / \mathrm{L})$ were measured by using the respective assays from Biolabo (Maizy, France). Plasma glucose levels were determined by using the GAGO-20 kit from Sigma Aldrich (Saint-Quentin Fallavier, France).

\section{Adipokines assays}

Total plasma ADP, Visf and Chem levels were determined with commercially available chicken total ADP, Visf and Chem enzyme-linked immunosorbent assays (ELISA) (Chicken Total Adiponectin Elisa reference: E12A0125, Chicken Visf Elisa reference: E12V0003 and Chicken Chem Elisa reference: E12C0104), respectively, obtained from Hölzel Diagnostika (Koln, Germany). The measurements have been performed according to the manufacturer's protocol, with an intra-assay coefficient of variation $<6 \%$. The sensitivity of the kits was $1 \mathrm{ng} / \mathrm{mL}$ for Visf, $0.1 \mathrm{ng} / \mathrm{mL}$ for total ADP and $1 \mathrm{pg} / \mathrm{mL}$ for Chem..

\section{RNA extraction and determination of ADP, Visf, Chem, AdipoR1, AdipoR2, CMKLR1, CCRL2 and GPR1 mRNA expression by RT-qPCR}

Total RNA of different tissues (heart, liver, AT, pectoral and leg muscles) and GC and TC was extracted on ice with an ultraturax homogenizer in TRIzol $^{\circ}$ reagent according to manufacturer's recommendation (Invitrogen ${ }^{\text {Tx }}$ by Life technologies ${ }^{\mathrm{Tm}}$, Villebon sur Yvette, France). A treatment with DNaseI using the DNA-free ${ }^{\text {tu }}$ Kit (Ambion ${ }^{\circ}$ by Life technologies ${ }^{\mathrm{Tw}}$, Villebon sur Yvette, France) was performed on the total RNAs. RNA quantity was assessed with a NanoDrop Spectrophotometer (Thermofisher, Villebonsur-Yvette, France). Reverse transcription (RT) of total RNA $(1 \mu \mathrm{g})$ was performed for 1 hour at $37^{\circ} \mathrm{C}$ in a $20 \mu \mathrm{l}$ mixture as previously described [23]. Real-time PCR using SYBR Green Supermix (Bio-Rad, Marnes la Coquette, France) and $250 \mathrm{nM}$ of specific primers as described in Table 2 (Invitrogen $^{\mathrm{Tw}}$ by Life technologies ${ }^{\mathrm{Tm}}$, Villebon sur
Yvette, France) in total volume of $20 \mu \mathrm{l}$ in a MyiQ Cycle device (Bio-Rad, Marnes-la-Coquette, France) was used to quantify adipokine and its receptor mRNA expression. Samples were tested in duplicate on the same plate and PCR amplification with water, instead of cDNA, was performed systematically as a negative control. After incubation for 2 minutes at $50{ }^{\circ} \mathrm{C}$ and a denaturation step of 10 minutes at $95^{\circ} \mathrm{C}$, samples were subjected to 40 cycles (30 seconds at $95{ }^{\circ} \mathrm{C}, 30$ seconds at $60{ }^{\circ} \mathrm{C}, 30$ seconds at $72{ }^{\circ} \mathrm{C}$ ), following by the acquisition of the melting curve. Primers' efficiency (E) was performed from serial dilutions of a pool of obtained cDNA and ranged from 1.80 to 2.00. Three reference genes were used: RPL-15, ACTR3 and EEF1A1. For each gene, expression was calculated according to primer efficiency and $\mathrm{Cq}$ : expression $=\mathrm{E}^{-\mathrm{Cq}}$. Then, relative expression of gene of interest/reference gene was analysed.

\section{Antibodies}

The chicken and turkey anti-Visf antibody was produced by immunizing two rabbits with a 18 -amino acid peptide corresponding to a region of chicken and turkey Visf located at the middle of the mature protein (Fig. 1a). When used in Western immunoblotting, the antiserum detected an approximately $52 \mathrm{kDa}$ protein in turkey plasma, AT and leg muscle lysates resolved by reducing with SDS-PAGE (Fig. 1a). We demonstrated the specificity of the antiserum by showing that the $52 \mathrm{kDa}$ signal in turkey plasma, AT and leg muscles lysates was eliminated when immunoblotting was performed in the presence of pre-immune rabbit serum or in the absence of chicken or turkey Visf antiserum (Fig. 1a). Furthermore, by using this Visf antiserum we confirmed that Visf is mainly expressed in muscles and not in adipose tissue in chicken. (Fig. 1a). For detection of ADP in turkey plasma, we used a bovine ADP antiserum that recognizes the ADP monomer $(30 \mathrm{kDa})$ in both adipose tissue and plasma similarly to bovine and chicken species (Fig. 1b).

Table 2 Oligonucleotide primer sequences

\begin{tabular}{|c|c|c|c|}
\hline Genes & Product size & Forward & Reverse \\
\hline$\beta$-actin & $188 \mathrm{bp}$ & 5'-ACGGAACCACAGTTTATCATC-3' & 5'-GTCCCAGTCTTCAACTATACC-3' \\
\hline RPL-15 & $194 \mathrm{bp}$ & 5'-TGTGATGCGTTTCCTCCTTGG-3' & 5'-CCATAGGTTGCACCTITTGGG-3' \\
\hline EF1-a & $90 \mathrm{bp}$ & 5'-AGCAGACTTTGTGACCTTGCC-3' & 5'-TGACATGAGACAGACGGTTGC-3' \\
\hline Visfatin & $502 \mathrm{bp}$ & 5'-CGTTCAGCCCATTTGGTGA-3' & 5'-AGTGGTGCCTCTGGACTTCG-3' \\
\hline Chemerin & $314 \mathrm{bp}$ & 5'-CGCGTGGTGAAGGATGTG-3' & 5'-CGACTGCTCCCTAAAGAGGAACT-3' \\
\hline CMKLR1 & $403 \mathrm{bp}$ & 5'-CGGTCAACGCCATTTGGT-3' & 5'-GGGTAGGAAGATGTTGAAGAGGAA-3' \\
\hline CCRL2 & $391 \mathrm{bp}$ & 5'-CACGCAGTGTTTGCTTTAAAAGC-3' & 5'-CAACAGCCCACGTGACAATG-3' \\
\hline GPR1 & $250 \mathrm{bp}$ & 5'-ACCTGCCTGAGGAAGAAGAA-3' & 5'-AAAGGCCAGTGGAAGCCCAT-3' \\
\hline Adiponectin & $350 \mathrm{bp}$ & 5'-ACAGGTGCAGAAGGACCGAG-3' & 5'-AAGACAGAGCCGCTTGCTTG-3' \\
\hline AdipoR1 & $350 \mathrm{bp}$ & 5'-GAATACACACCGAGACGGGC-3' & 5'-GCCCAAGACGCAGACAATGG-3' \\
\hline AdipoR2 & $345 \mathrm{bp}$ & 5'-GAGACTGGCAACATCTGGAC-3' & 5'-TGCGATGCCCAGGACACAAA-3' \\
\hline
\end{tabular}




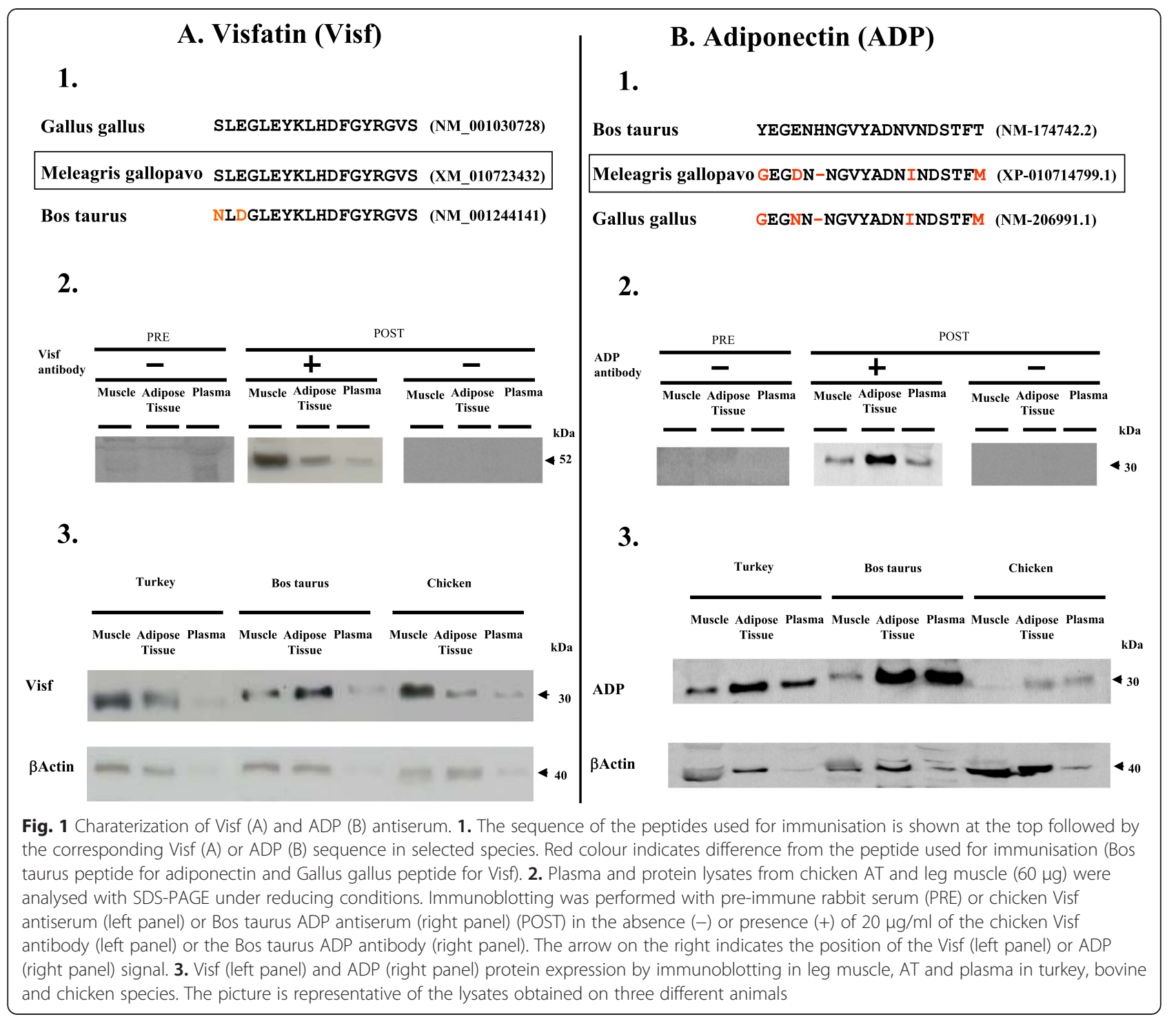

For detection of ADIPOR1 and ADIPOR2 we used antibodies from Abcam (Paris, France), Ab50675 and Ab40446, respectively. CMKLR1 (H160, SC66829) and CCRL2 (SAB2100371) antibodies were obtained from Sigma (Saint-Quentin-Fallavier, France) and Tebu-Bio (Le Perray-en-Yvelines, France), respectively.

\section{Detection and quantification of ADP, Visf, ADIPOR1, ADIPOR2, CMKLR1 and CCRL2 in turkey plasma and/or tissues by Western-Blot analysis}

Lysates of tissues were prepared on ice with an ultraturax homogenizer in lysis buffer containing $10 \mathrm{mM}$ Tris (pH 7.4), $150 \mathrm{mM} \mathrm{NaCl}, 1 \mathrm{mM}$ EthyleneDiamineTetraacetic Acid , $1 \mathrm{mM}$ Ethylene Glycol Tetraacetic Acid and $0.5 \%$ Nonidet P-40 supplemented with various protease inhibitors $(2 \mathrm{mM}$ phenylmethanesulfonylfluoride, $10 \mu \mathrm{g} / \mathrm{ml}$ leupeptin, $10 \mu \mathrm{g} / \mathrm{ml}$ aprotinin) and phosphatase inhibitors
(100 mM sodium fluoride, $10 \mathrm{mM}$ sodium pyrophosphate, $2 \mathrm{mM}$ sodium orthovanadate). Lysates were incubated on ice for $30 \mathrm{~min}$ before centrifugation at $12,000 \times \mathrm{g}$ for $20 \mathrm{~min}$ at $4{ }^{\circ} \mathrm{C}$. The pellet was eliminated and the samples were stored at $-80{ }^{\circ} \mathrm{C}$. The protein concentration of samples was measured using the bicinchoninic acid (BCA) protein assay (Interchim, Montluçon, France). Eighty micrograms of proteins were denaturated with Laemmli buffer for 5 minutes to $95{ }^{\circ} \mathrm{C}$. Plasma samples $(1 \mu \mathrm{L})$ were diluted with $10 \mu \mathrm{L}$ of lysis buffer and mixed with sample buffer (final concentrations: $0.064 \mathrm{M}$ Tris $\mathrm{HCl}, \mathrm{pH}$ 6.8, 1 \% SDS, $0.01 \%$ bromophenol blue, $10 \%$ glycerol). To convert the multimers of adiponectin to dimers and monomers, the samples were reduced at a final concentration of $200 \mathrm{mM}$ dithiothreitol and denatured for $5 \mathrm{~min}$ at $95{ }^{\circ} \mathrm{C}$. Denatured proteins extracts from tissue $(80 \mu \mathrm{g})$ and plasma were submitted to electrophoresis in a 
$12 \%$ (w:v) SDS-polyacrylamide gel. Non denatured plasma proteins were submitted to electrophoresis in a Tris-glycine gel 4-20\%. The fractionated proteins were transferred to a nitrocellulose membrane. The membranes were blocked with Tris-buffered saline containing $0.05 \%$ Tween 20 (TBST) and $5 \%$ milk for $30 \mathrm{~min}$ at RT. They were then incubated at $4{ }^{\circ} \mathrm{C}$ with appropriate primary antibodies at a 1/1000 final dilution. Finally, the blots were incubated for 1 h30 minutes at room temperature with a HorseRadish Peroxidase-conjugated anti-rabbit or anti-mouse IgG (dilution 1/5000). Proteins of interest were detected by enhanced chemiluminescence (Western Lightning Plus-ECL, Perkin Elmer, Villebon-sur-Yvette, France) with a G-box SynGene (Ozyme, St Quentin en Yvelines, France) and GeneSnap software (Ozyme, St Quentin en Yvelines, France). Then proteins were quantified by GeneTools software. The results were expressed as the intensity signal in arbitrary units after normalization.

\section{Statistical analysis}

All experimental data are presented as means \pm SEM. Two-way analysis of variance was used to test for differences in the expression levels of adipokines and their receptors in TC and GC at different follicle developmental stages. One-way analysis of variance was used to test for differences in plasma total adiponectin, Visf and Chem at different stages of laying period, in body weight, plasma levels of glucose, cholesterol, triglycerides and phospholipids of turkeys at different stages of laying period, and in peripheral tissue relative gene expression at the end of laying in turkeys. The level of statistical significance was set at $p<0.05$. Statview software was used for all statistical tests. The relationships between quantitative parameters (plasma glucose, cholesterol, triglycerides and phospholipids concentrations) were investigated by Pearson's correlation analyses, with the CORR procedure of SAS software.

\section{Results}

Expression of ADP, Chem, Visf, AdipoR1, AdipoR2, CMKLR1, CCRL2 and GPR1 in different peripheral tissues in turkeys

We studied the expression of adipokines (ADP, Chem, Visf) and ADP and Chem receptors (AdipoR1, AdipoR2 and CMKLR1, CCRL2 and GPR1) by RT-qPCR in heart $(\mathrm{H})$, liver (Liv), adipose tissue $(\mathrm{AT})$, pectoral $(\mathrm{pM})$ and leg ( $\operatorname{LgM})$ muscles in turkeys at the end of the laying period. As shown in Table 3, mRNA Visf was highly expressed in pectoral muscle as compared to adipose tissue, the liver, heart or leg muscles whereas mRNA Chem was mainly present in the liver and ADP in adipose tissue. As described in mammals, we observed that the expression of adiponectin receptors was tissue specific whereas those of CMKLR1 and GPR1 was
Table 3 Peripheral tissue relative gene expression at the end of laying in turkeys ${ }^{1}$

\begin{tabular}{|c|c|c|c|c|c|}
\hline & Heart & Liver & $\begin{array}{l}\text { Adipose } \\
\text { tissue }\end{array}$ & $\begin{array}{l}\text { Pectoral } \\
\text { muscle }\end{array}$ & $\begin{array}{l}\text { Muscle of } \\
\text { the leg }\end{array}$ \\
\hline \multirow[t]{3}{*}{ Visfatin } & 0.01 & 0.04 & 0.06 & 0.98 & 0.30 \\
\hline & \pm 0.001 & \pm 0.012 & \pm 0.008 & \pm 0.277 & \pm 0.103 \\
\hline & $a$ & a & $\mathrm{a}$ & $b$ & a \\
\hline \multirow[t]{3}{*}{ Chemerin } & 0.23 & 3.69 & 0.35 & 0.17 & 0.31 \\
\hline & \pm 0.090 & \pm 0.346 & \pm 0.172 & \pm 0.028 & \pm 0.090 \\
\hline & a & $b$ & $\mathrm{a}$ & a & $\mathrm{a}$ \\
\hline \multirow[t]{3}{*}{ CMKLR1 } & 0.003 & 0.001 & 0.002 & 0.003 & 0.003 \\
\hline & \pm 0.001 & \pm 0.001 & \pm 0.001 & \pm 0.001 & $\pm 1.10^{-4}$ \\
\hline & a & $a$ & a & a & a \\
\hline \multirow[t]{3}{*}{ GPR1 } & 0.02 & 0.01 & 0.02 & 0.03 & 0.02 \\
\hline & \pm 0.002 & \pm 0.002 & \pm 0.003 & \pm 0.004 & \pm 0.004 \\
\hline & $\mathrm{a}$ & $\mathrm{a}$ & $\mathrm{a}$ & & $\mathrm{a}$ \\
\hline \multirow[t]{3}{*}{ CCRL2 } & 0.007 & 0.01 & 0.03 & 0.03 & 0.02 \\
\hline & \pm 0.003 & \pm 0.005 & \pm 0.008 & \pm 0.004 & \pm 0.006 \\
\hline & $a$ & $a$ & $b$ & $b$ & $a$ \\
\hline \multirow[t]{3}{*}{ Adiponectin } & 0.006 & 0.001 & 0.181 & 0.058 & 0.031 \\
\hline & \pm 0.004 & \pm 0.001 & \pm 0.070 & \pm 0.024 & \pm 0.004 \\
\hline & a & a & $b$ & a & a \\
\hline \multirow[t]{3}{*}{ AdipoR1 } & 0.12 & 0.02 & 0.05 & 0.19 & 0.18 \\
\hline & \pm 0.029 & \pm 0.003 & \pm 0.005 & \pm 0.037 & \pm 0.002 \\
\hline & $a$ & $b$ & $b$ & $c$ & $c$ \\
\hline \multirow[t]{3}{*}{ AdipoR2 } & 0.21 & 0.47 & 0.10 & 0.28 & 0.25 \\
\hline & \pm 0.074 & \pm 0.068 & \pm 0.006 & \pm 0.020 & \pm 0.094 \\
\hline & $a$ & $b$ & $a$ & $\mathrm{a}$ & $a b$ \\
\hline
\end{tabular}

a-c means within a row without a common letter differ $(P<0.05)$.

${ }^{1}$ Relative expression was measured relatively to the geometric mean of 3 housekeeping gene expression (RPL-15, ACTR3 and EEF1A1) by real-time reverse-transcription PCR. Results are presented as means \pm SEM. Genes and expression values written in bold indicate genes with difference in expression between tissues.

ubiquitous. Indeed, AdipoR1 was highly expressed not only in pectoral muscle but also in leg muscle. At the opposite, AdipoR2 mRNA was mainly present in the liver. CCRL2 expression was higher in pectoral muscle and adipose tissue as compared to other tissues. We confirmed the results obtained by RT-qPCR at the protein levels through immunoblotting for ADP, Visf, AdipoR1, AdipoR2, CMKLR1 and CCRL2 (Fig. 2).We failed to detect Chem and GPR1 protein by immunoblot because we did not find good antibodies that recognize chicken Chem and GPR1.

\section{Expression of ADP, Chem, Visf, AdipoR1, AdipoR2, CMKLR1, CCRL2 and GPR1 in ovarian cells in hierarchical follicles}

In mammals, some studies localized adipokines and their receptors in ovarian cells in different species [24-27]. In 


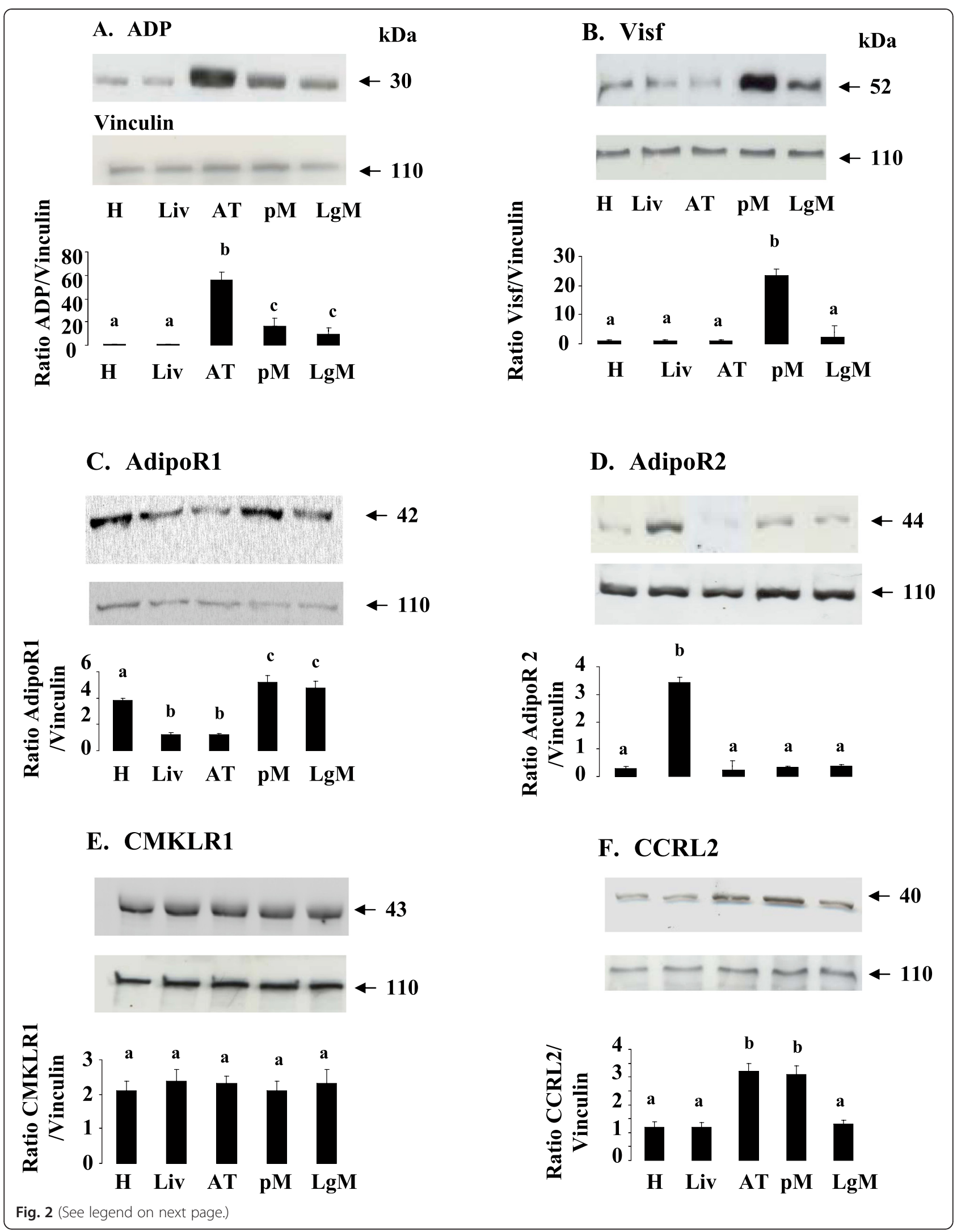


(See figure on previous page.)

Fig. 2 ADP (a), Visf (b), AdipoR1 (c), AdipoR2 (d), CMKLR1 (e) and CCRL2 (f) protein expression in peripheral tissues. ADP (a), Visf (b), AdipoR1 (c), AdipoR2 (d), CMKLR1 (e), and CCRL2 (f), protein levels were analyzed by western blotting in different peripheral tissues (Heart (H), Liver (Liv), Adipose Tissue (AT, pectoral (pM) and leg muscles (LgM) from six animals. Vinculin was used as a loading control. Data are represented as mean $\pm \operatorname{SEM}(n=6$ animals). Different letters indicate a significant difference

turkeys, we showed that mRNA expression of ADP, Chem and Visf was higher in theca cells compared to granulosa cells in both F1 and F3/4 hierarchical follicles (Fig. 3). Similar data was observed for AdipoR2, CMKLR1, CCRL2 and GPR1 receptors (Fig. 4). In both theca and granulosa cells, the expression of ADP, Chem and Visf was similar in F1 and F3/4 hierarchical follicles (Fig. 3). In contrast, in granulosa cells, AdipoR1 and AdipoR2 mRNA expression was higher in F1 than in F3/4 hierarchical follicles whereas CMKLR1, CCRL2 and GPR1 expression was unchanged irrespective of the differentiation stage of the follicle (Fig. 4). We confirmed the results obtained by RT-qPCR at the protein levels by immunoblotting (Fig. 5).

\section{Concentration of plasma ADP, Chem and Visf in turkey during a laying cycle}

We next determined the plasma profile of adipokines (ADP, Chem and Visf) during a laying period in Meleagris gallopavo turkeys (heavy strain Converter) from a commercial breeding unit. We measured plasma levels of ADP and Visf at three different stages of laying (start, peak and end) by using a commercial Elisa chicken kit and by immunoblotting. For the methodology, we used a specific

\section{A. ADP}

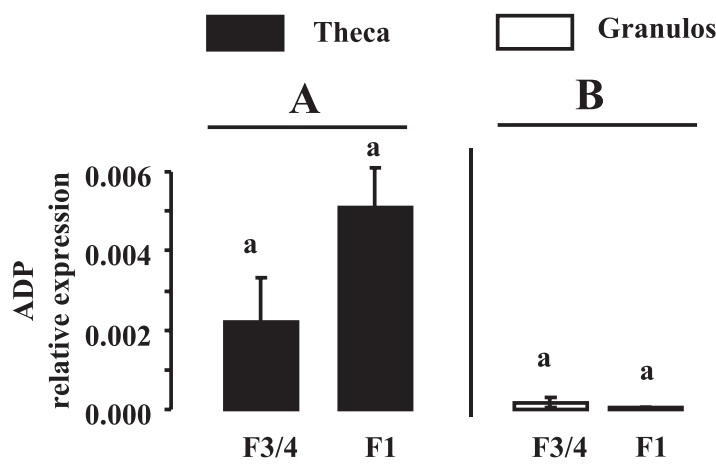

\section{B. Visf}

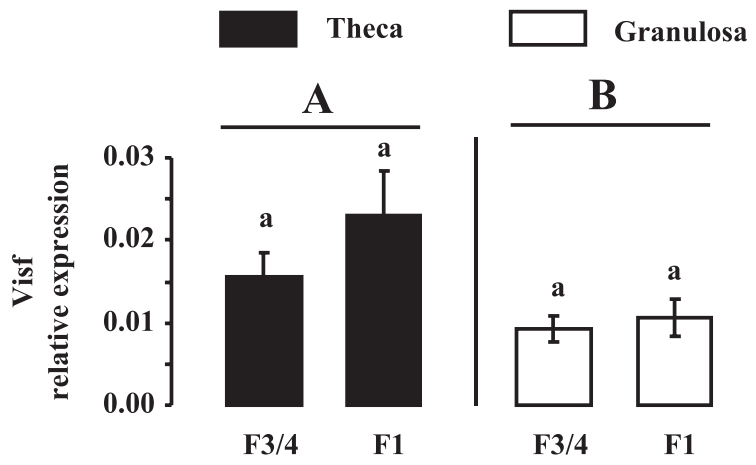

\section{Chemerin}

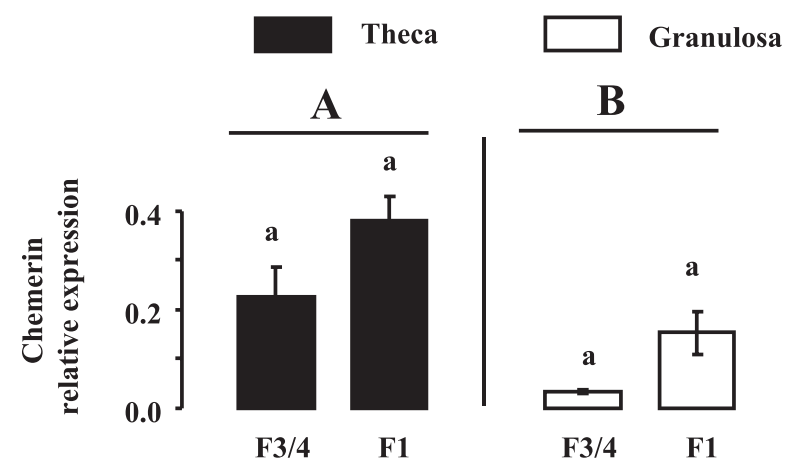

Fig. $3 \mathrm{ADP}(\mathbf{a})$, Visf (b), and Chem (c), mRNA expression in theca and granulosa cells from F3/4 and F1 hierarchical follicles. Relative expression of $\operatorname{ADP}(\mathbf{a})$, Visf (b), and Chem (c), mRNA in theca and granulosa cells from turkey F3/4 and F1 hierarchical follicles, based on real-time RT-PCR. Total RNA from all types of ovarian cells and hierarchical follicles was treated with DNAse and reverse transcribed as described in Materials and Methods. CDNAs were used in separate real-time quantitative PCR analyses of ADP, Visf and Chem mRNA or reference genes with SYBR green as the dye. ADP, Visf and Chem expressions were measured relative to the geometric mean of the expression of three reference genes as described in Materials and Methods. Results are means \pm SEM from six different animals in each follicular stage. Different capital letters indicate a significant effect of the type of cells (Theca vs Granulosa cells) whereas lower case letters indicate a significant effect of the follicular stage (F3/4 vs F1) 


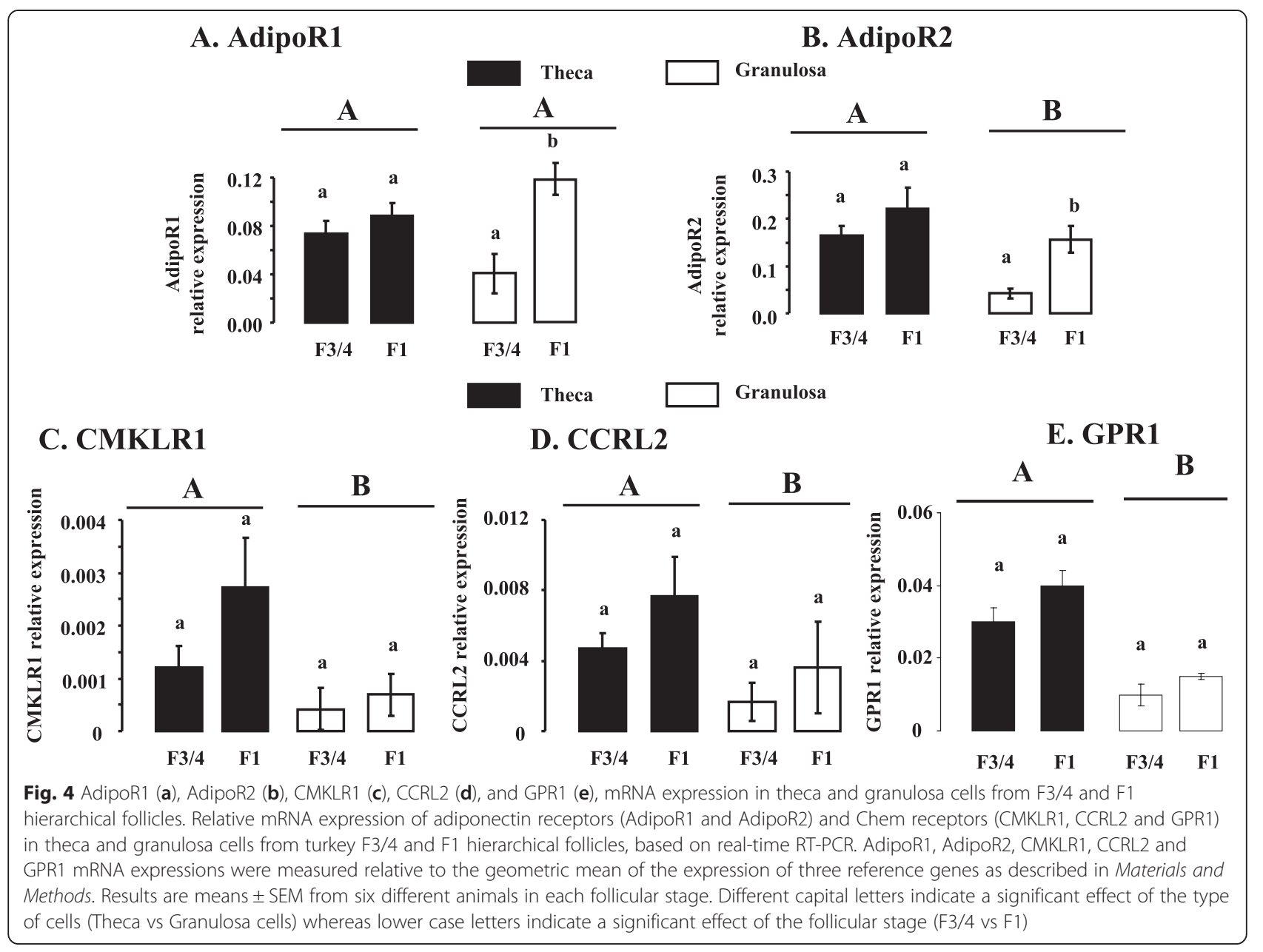

chicken and turkey anti-Visf antibody and a bovine antiADP antibody that cross-reacts with chicken and turkey species as described in the materials and methods. For the determination of plasma levels of Chem, we used only a commercial Elisa chicken kit since we found no antibodies suitable for immunoblotting.

As shown in Fig. 6, we observed by Elisa and immunoblotting that Visf plasma levels were significantly decreased at the end compared to the beginning of the laying period. Similar results were noted for the plasma levels of total ADP as determined using the Elisa kit (Fig. 7a) or for those of ADP monomeric (Fig. 7b) or hexameric forms (Fig. 7c) obtained by Western blot. Indeed, for example, in non denaturing conditions, we showed through immunoblotting that the hexameric form of ADP that is the main form revealed in these conditions is reduced by about three-fold at the end compared to the start of the laying period (Fig. 7c). As showed in Fig. 8, plasma Chem levels were also significantly reduced during the laying period.

\section{Correlations between adipokines concentrations and} different blood parameters during a laying season

We next investigated whether the plasma concentration of ADP, Visf or Chem was correlated with plasma concentration of different blood biochemistry parameters such as glucose, cholesterol, triglycerides and phospholipids. Plasma glucose levels significantly increased during the entire laying period whereas plasma phospholipids and triglycerides levels decreased at the end (Table 1). On the contrary, plasma cholesterol levels remained unchanged (Table 1). To determine whether the plasma adipokines levels were correlated with those of plasma biochemistry parameters, a Pearson correlation coefficient test was performed. As showed in Table 4, we observed that during the entire laying season the plasma concentration of the three adipokines studied was negatively correlated with glycaemia. Moreover, plasma Chem levels were strongly negatively correlated with the plasma biochemistry parameters studied (glucose, cholesterol, triglycerides and phospholipids) whereas little 


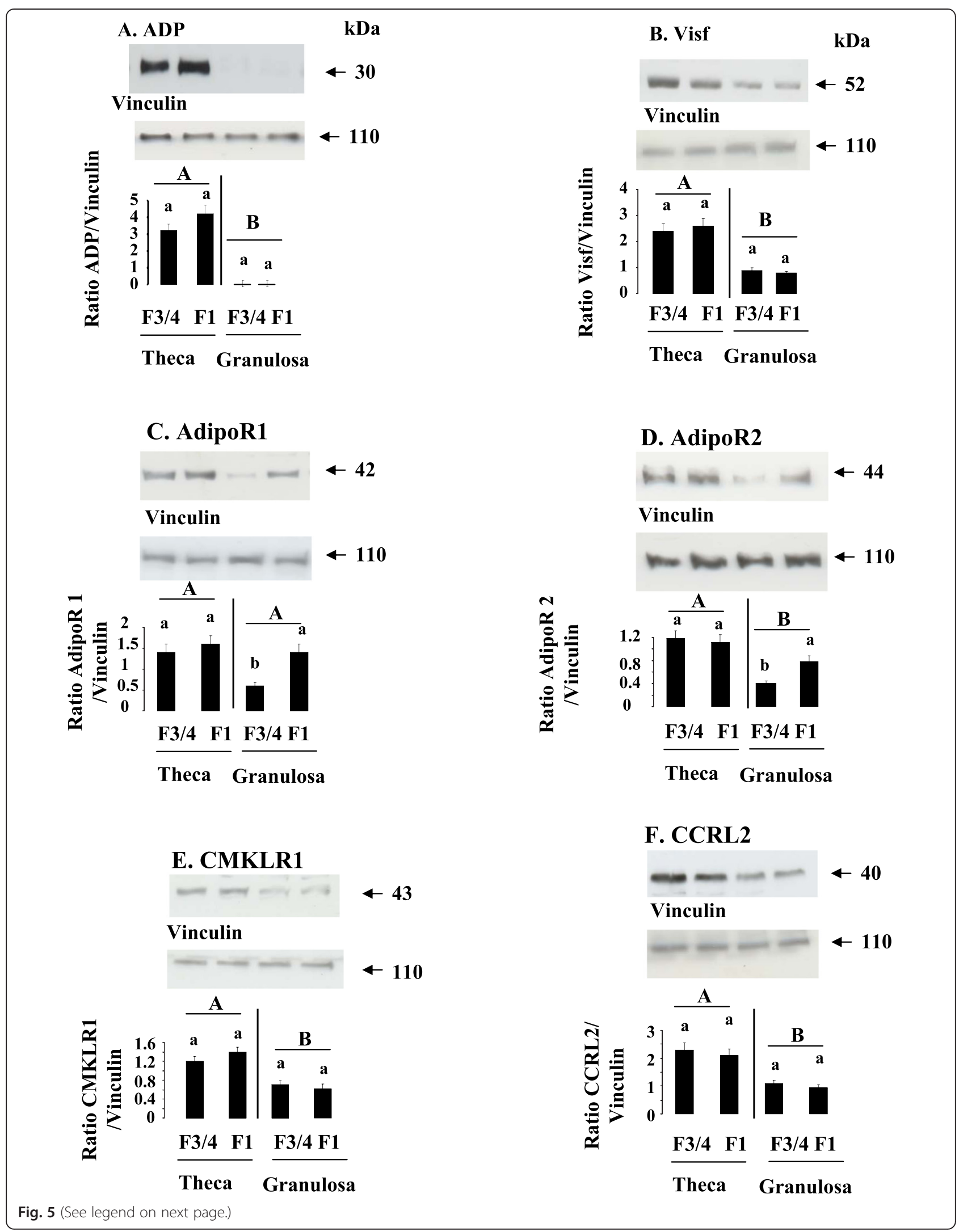


(See figure on previous page.)

Fig. 5 ADP (a), Visf (b), AdipoR1 (c), AdipoR2 (d), CMKLR1 (e), and CCRL2 (f), protein expression in ovarian cells. ADP (a), Visf (b), AdipoR1 (c), AdipoR2 (d), CMKLR1 (e), and CCRL2 (f), protein levels were analyzed by western blotting in theca and granulosa cells from F1 and F3/4 follicles. Vinculin was used as a loading control. Results are represented as means \pm SEM ( $n=6$ animals). Different capital letters indicate a significant effect of the type of cells (Theca vs Granulosa cells) whereas lower case letters indicate a significant effect of the follicular stage (F3/4 vs F1). Data are represented as mean \pm SEM. ( $n=6$ animals)

significant differences were observed for ADP and Visf (Table 4).

\section{Discussion}

In this study, we showed for the first time that plasma adipokines including ADP, Visf and Chem decreased and were negatively correlated to plasma glucose during the laying period in turkey. Plasma Chem was also negatively correlated to plasma cholesterol, triglycerides and phospholipids. Furthermore, we observed that Chem was mainly expressed in the turkey liver while ADP and Visf were mainly expressed in the ATand pectoral muscles, respectively. In turkey, ADP, Visf and Chem and their receptors are expressed not only in peripheral tissues but also in ovarian cells. In ovarian cells, ADP, Visf, Chem and their receptors are more highly expressed in theca cells than in granulosa cells excepted for AdipoR1.

In this paper, for the first time, we studied the expression of Chem and its receptors, CMKLR1, GPR1 and CCRL2 in tissue and plasma in turkeys, a non-mammalian species. Chem also known as retinoic acid receptor responder protein 2 (RARRES2), is a $16 \mathrm{kDa}$ protein secreted in an inactive form as proChem and is activated through cleavage of the C-terminus via inflammatory and coagulation serine proteases [28]. It is a novel adipokine that regulates adipocyte development and metabolic function [29]. In mammals, Chem expression is ubiquitous. However, several studies showed a higher expression of Chem in the liver as compared to other tissues in human and mice [30]. Furthermore, several reports have shown that liver injury may be associated with circulating Chem levels $[31,32]$ and that the liver may be a contributor to serum levels [33]. In turkeys, we observed that Chem is more highly expressed in liver than in AT or muscle. It will be interesting to study hepatic Chem expression during the fattening of birds, including ducks and hens. Active Chem exerts its action by binding to its extracellular receptor CMKLR1 on adipocytes and/or CCRL2 on activated macrophages or GPR1 on brain cells [34]. Only one study investigated the mRNA expression of Chem and its receptors in chicken adipose tissue [35]. Chem is expressed at higher levels in the abdominal fat of lean chickens compared to fat chickens [35]. Thus, Chem appears to be associated with leanness in chickens. On the contrary, a majority of human data indicate that plasma Chem is elevated in obesity/diabetes [36] and in inflammatory states $[37,38]$. Animal studies reported the parallel findings in that obese and diabetic mice have elevated circulating levels of Chem [33, 39]. In turkeys, we showed that Chem plasma levels decrease during the laying period. Furthermore, they were negatively correlated with glycaemia and plasma cholesterol, triglycerides and
A. ELISA
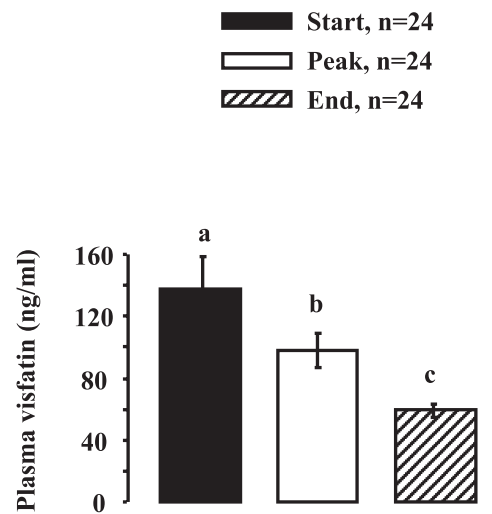

B.Western-blot

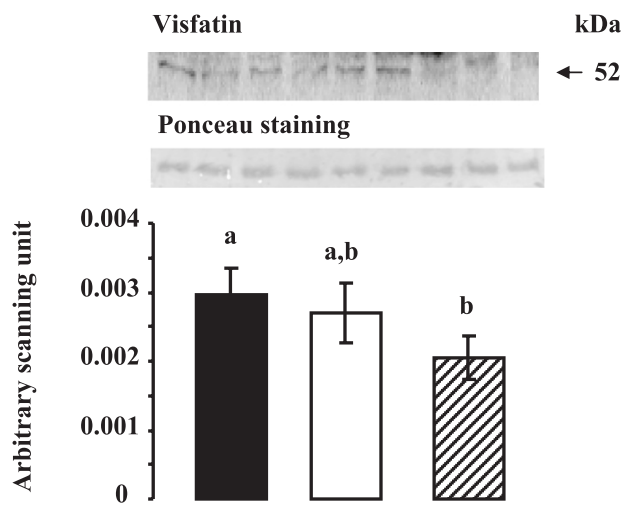

Fig. 6 Plasma Visf concentration as determined by ELISA and immunoblot in turkey during a laying cycle. a. Plasma Visf levels in turkey at different stages of laying [start (S:32 week-old), peak (P: 35 week-old), end (E: 55 week-old)] based on ELISA. All serums samples used in Western blotting in denaturing conditions (b) contained equal amounts of protein; this was confirmed by staining the nitrocellulose membrane with Ponceau. Blots were quantified using an arbitrary scale. The letters above each bar indicate significant differences $(p<0.05)$. Data are represented as mean \pm SEM. ( $n=24 /$ stage of laying period) 


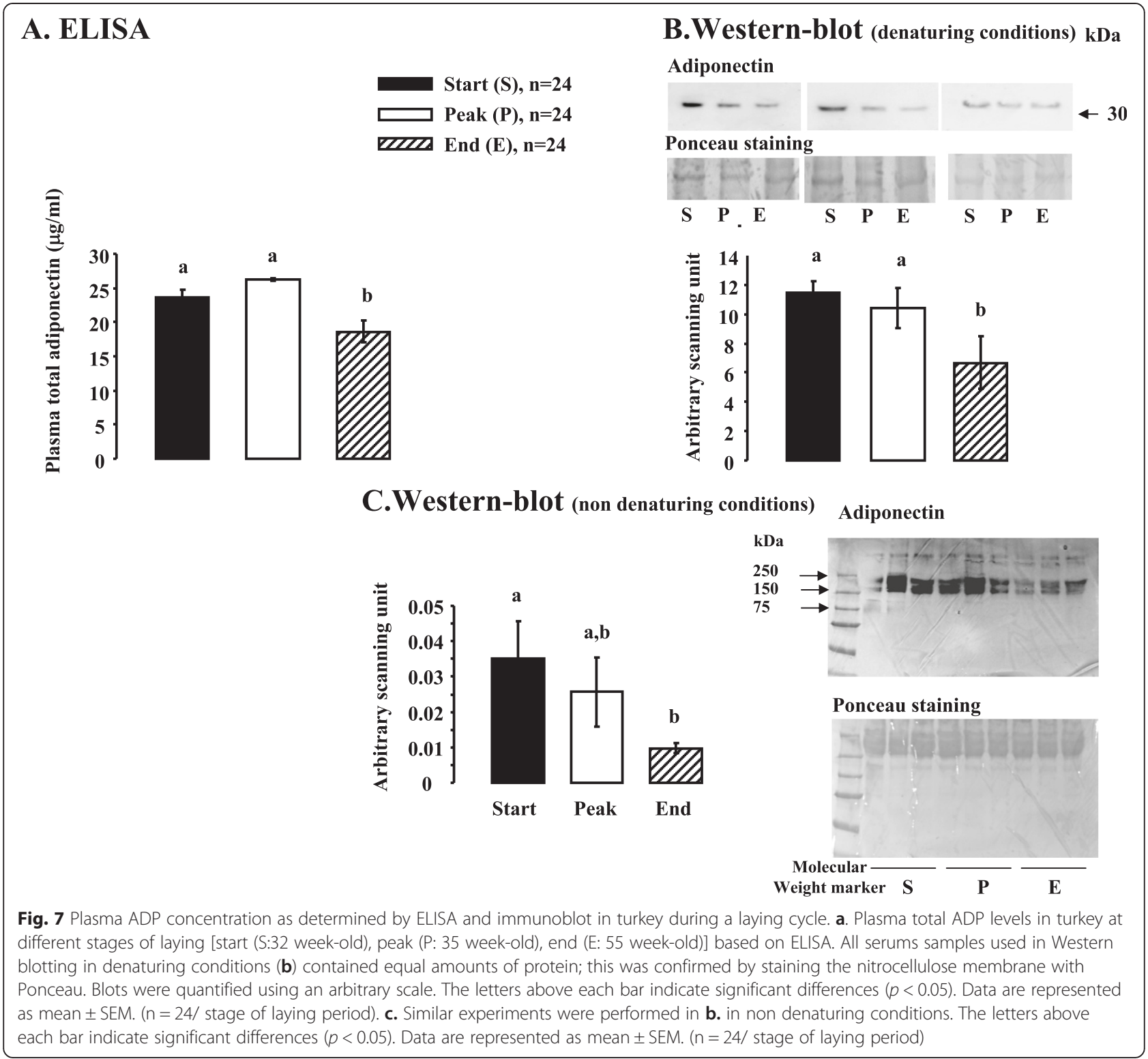

phospholipids. As a limitation, it is acknowledged that the Elisa assay used in our study to measure plasma levels of Chem does not distinguish between active Chem and inactive proChem. Thus, total measured Chem concentrations might not equate to the actual amount of active Chem. In the plasma of healthy human, inactive proChem represents $80 \%$ of total Chem [40]. This latter data is still unknown in birds. In the literature, the plasma and serum concentration of total Chem was reported to be about 3 to $4.4 \mathrm{nM}$ in humans and 0.5 to $0.6 \mathrm{nM}[41,28]$ in mice [42]. Here, we determined a concentration of $1 \mathrm{nM}$ in turkeys. In humans, plasma Chem levels are positively correlated with body fat, plasma glucose and triglyceride levels and lipid metabolism [43-46]. In our present study, we observed opposite results in turkey. Thus, as with chicken species, Chem could be associated with leanness and not with fattening in turkeys.

Similarly to Chem, we found that the plasma levels of Visf were also significantly decreased during the laying period. In birds, plasma Visf levels have been already determined by enzyme immunoassays in prepubertal and adult broiler chickens and hens [14, 22]. In chickens, plasma Visf levels are at least 28-fold higher in the adult chickens (about $300 \mathrm{ng} / \mathrm{ml}$ ) compared with prepubertal male chickens (about $10 \mathrm{ng} / \mathrm{ml}$ ) [14]. Furthermore, Krzysik-Walker et al., 2008 have observed that plasma Visf levels were significantly higher in 8-wk-old compared with 4-wk-old chickens [19]. On the contrary, we showed in our lab that in hens, Visf levels in plasma collected from adult animals (about $60 \mathrm{ng} / \mathrm{ml}$ at 52 week-old) were 


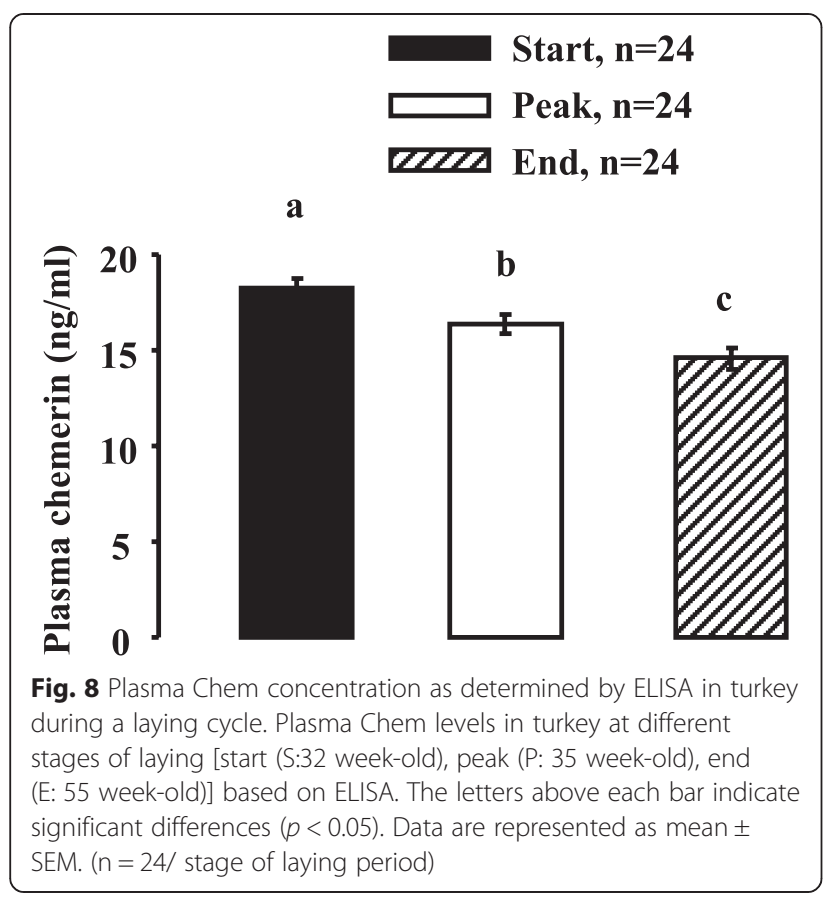

significantly lower than in plasma from young prepubertal (about $100 \mathrm{ng} / \mathrm{ml}$ at 3 weeks old) hens [22]. This latter data is consistent with our results obtained in turkeys showing a decrease in plasma Visf between the start (32 weeks old) and the end (55 weeks old) of the laying period. In chickens, Visf is considered to act more as a myokine than an adipokine [19]. We confirmed these results in turkeys as Visf is strongly expressed in muscles as compared to AT or the liver. However, we found that Visf is also expressed in ovarian cells and more precisely more in theca cells than in granulosa cells in turkeys. The role of Visf in these cells remains to be explored.

ADP is one of the most abundant plasma proteins in both birds and mammals. Unlike Visf, ADP exists in different molecular forms: monomer and multimers, which can be classified in high (18 or more ADP monomers), medium (a hexamer composed of two homotrimers) and low molecular weight (a homotrimer of three ADP monomers)

Table 4 Coefficient of Pearson's correlation

\begin{tabular}{llll}
\hline & Adiponectin & Chemerin & Visfatin \\
\hline Glucose & -0.402 & -0.5267 & -0.223 \\
Cholesterol & $p=0.01$ & $p=0.0004$ & $p=0.0534$ \\
& 0.0197 & -0.4812 & 0.0117 \\
Triglycerides & $p=0.91$ & $p=0.0014$ & $p=0.93$ \\
& 0.058 & -0.4353 & 0.1469 \\
Phospholipids & $p=0.73$ & $p=0.0045$ & $p=0.26$ \\
& -0.065 & -0.39579 & 0.2137 \\
& $p=0.707$ & $p=0.0104$ & $p=0.10$ \\
\hline
\end{tabular}

[47]. In human and poultry, it is the high molecular weight form which is predominantly present and active in plasma $[48,15]$. In turkeys, we showed by Elisa kit that total ADP plasma levels decrease at the end of laying period when animals lose weight and their glycaemia increase whereas their plasma triglycerides and phospholipids levels decreases. We confirmed these results by immunoblot in denaturing and non denaturing conditions. In these latter conditions, we observed bands of about $180 \mathrm{kDa}$ suggesting that medium molecular weight (a hexamer composed of two homotrimers) isoforms are present in turkey plasma. In male chickens, plasma ADP levels were found to be significantly lower in 8-wk compared with 4-wk-olds and inversely related to abdominal fat pad mass [15]. In broiler chickens, Tahmoorespur et al (2010) showed that ADP mRNA expression in AT was inversely related to chicken belly fat deposition levels [49]. Furthermore, more recently, Yan et al., 2013 [50] observed that ADP inhibited lipid deposition and differentiation of chicken preadipocytes. An inverse relationship between plasma triglyceride and serum ADP has been described in humans [51]. In our study, we did not observe any significant correlation between plasma ADP and triglycerides in turkeys. However, we showed a negative correlation between glycaemia and plasma ADP that is already described in humans since ADP is known to increase insulin sensitivity. As in humans and mice, the chicken ADP gene is mainly expressed in adipose tissue [16]. However, it is also widely expressed in other tissues $[16,17]$. We obtained similar data in turkeys. Indeed we found that ADP mRNA expression was the highest in AT, followed by the pectoral muscle and the heart and liver. As in humans and mice, we found that AdipoR1 is mainly expressed in muscle whereas AdipoR2 is more expressed in liver. We confirmed these results by Western blot in denaturing conditions.

Our data show that adipokines (ADP, Visf and Chem) and their receptors are present in ovarian cells in turkeys. More precisely, we observed that ADP expression is very low in granulosa cells. This data is consistent with those observed in humans [26, 27] or hen granulosa cells [18]. In this study, we found that AdipoR2 is higher expressed in theca cells as compared to granulosa cells. Furthermore, AdipoR2 is more expressed in F1 granulosa as compared to F3/4 granulosa suggesting that AdipoR2 could be involved in granulosa cell differentiation in turkeys. In human granulosa cells, our lab showed that AdipoR2 but not AdipoR1 could be implicated in the regulation of steroid production [52]. Thus, our results lead us to ask whether the adipokines could be fertility markers. In a recent work, we have showed that Visf decreases in vitro progesterone secretion by hen granulosa cells [22]. It will be interesting to correlate the plasma concentrations of adipokines with the fertility of animals (egg production but also embryo mortality). Expression of leptin receptor 
gene has been detected in the yolk sac of hen embryos [53]. It will be interesting to determine whether ADP, Visf and Chem and their receptors are present in the yolk sac and if their concentrations are correlated with parameters of fertility.

\section{Conclusions}

In conclusion, we show for the first time that ADP, Chem and Visf are expressed not only in plasma and peripheral tissues but also in ovarian cells in turkeys. Furthermore, plasma levels of these adipokines decrease at the end of the laying period when the animals lose weight, their glycaemia increases and their triglycerides and phospholipids plasma levels decrease.

\section{Competing interests}

The authors declare that there is no competing interest that could be perceived as prejudicing the impartiality of the research reported and that there are no financial or other potential conflicts of interest.

\section{Authors' contributions \\ $M D, M R$ and $C R$ participated in the design of the study, performing experiments and drafting the manuscript. JD conceived of the study and participated in its design and coordination and drafted the manuscript and advised on the statistical analysis. JPB, SB, GL, PF participated in the design of the study and carried out management of the animals, the collection of plasma and tissue samples, and participated in drafting the manuscript. DG performed the statistical analysis. All authors read and approved the final manuscript.}

\section{Acknowledgements}

The research was supported by a grant from the region Centre called "Adipofertikines" grant number: 32000407.

\section{Author details}

'INRA, UMR85, Unité Physiologie de la Reproduction et des Comportements, Nouzilly F-37380, France. ${ }^{2}$ CNRS, UMR6175, Nouzilly F-37380, France. ${ }^{3}$ Université François Rabelais, Tours F-37041, France. ${ }^{4}$ IFCE, Nouzilly F-37380, France. ${ }^{5}$ Fertilité et reproduction avicole (FERTIL'AVI), Rouziers-de-Touraine F-37360, France. ${ }^{6}$ Hendrix Genetics-Grelier, Saint Laurent de la Plaine F-49290, France.

Received: 30 April 2015 Accepted: 25 July 2015

Published online: 31 July 2015

\section{References}

1. Kershaw EE, Flier JS. Adipose tissue as an endocrine organ. J Clin Endocrinol Metab. 2004;89(6):2548-56. doi:10.1210/jc.2004-0395.

2. Reverchon M, Rame C, Bertoldo M, Dupont J. Adipokines and the female reproductive tract. Int J Endocrinol. 2014;2014:232454. doi:10.1155/2014/232454

3. Rodriguez-Pacheco F, Garcia-Serrano S, Garcia-Escobar E, Gutierrez-Repiso C, Garcia-Arnes J, Valdes S, et al. Effects of obesity/fatty acids on the expression of GPR120. Mol Nutr Food Res. 2014;58(9):1852-60. doi:10.1002/mnfr.201300666.

4. Kiezun M, Smolinska N, Maleszka A, Dobrzyn K, Szeszko K, Kaminski T. Adiponectin expression in the porcine pituitary during the estrous cycle and its effect on LH and FSH secretion. Am J Physiol Endocrinol Metab. 2014;307(11):E1038-46. doi:10.1152/ajpendo.00299.2014.

5. Tsao TS. Assembly of adiponectin oligomers. Rev Endocr Metab Disord. 2014;15(2):125-36. doi:10.1007/s11154-013-9256-6.

6. Yamauchi T, Iwabu M, Okada-Iwabu M, Kadowaki T. Adiponectin receptors: a review of their structure, function and how they work. Best Pract Res Clin Endocrinol Metab. 2014;28(1):15-23. doi:10.1016/j.beem.2013.09.003.

7. Mattern A, Zellmann T, Beck-Sickinger AG. Processing, signaling, and physiological function of chemerin. IUBMB Life. 2014;66(1):19-26. doi:10.1002/iub.1242
8. Reverchon M, Bertoldo MJ, Rame C, Froment P, Dupont J. CHEMERIN (RARRES2) decreases in vitro granulosa cell steroidogenesis and blocks oocyte meiotic progression in bovine species. Biol Reprod. 2014;90(5):102. doi:10.1095/biolreprod.113.117044.

9. Sun Z, Lei H, Zhang Z. Pre-B cell colony enhancing factor (PBEF), a cytokine with multiple physiological functions. Cytokine Growth Factor Rev. 2013;24(5):433-42. doi:10.1016/j.cytogfr.2013.05.006.

10. Simon J. Chicken as a useful species for the comprehension of insulin action. Critical reviews in poultry biology. 1989;2(2):121-48.

11. Akiba Y, Chida Y, Takahashi T, Ohtomo Y, Sato K, Takahashi K. Persistent hypoglycemia induced by continuous insulin infusion in broiler chickens. Br Poultry Sci. 1999:40(5):701-5. doi:10.1080/00071669987124.

12. Braun EJ, Sweazea KL. Glucose regulation in birds. Comp Biochem Physiol B: Biochem Mol Biol. 2008;151(1):1-9. doi:10.1016/j.cbpb.2008.05.007.

13. Ramachandran R, Maddineni S, Ocon-Grove O, Hendricks 3rd G, Vasilatos-Younken R, Hadley JA. Expression of adiponectin and its receptors in avian species. Gen Comp Endocrinol. 2013;190:88-95. doi:10.1016/j.ygcen.2013.05.004

14. Ocon-Grove OM, Krzysik-Walker SM, Maddineni SR, Hendricks 3rd GL, Ramachandran R. NAMPT (visfatin) in the chicken testis: influence of sexual maturation on cellular localization, plasma levels and gene and protein expression. Reproduction. 2010;139(1):217-26. doi:10.1530/REP-08-0377.

15. Hendricks 3rd GL, Hadley JA, Krzysik-Walker SM, Prabhu KS, Vasilatos-Younken R, Ramachandran R. Unique profile of chicken adiponectin, a predominantly heavy molecular weight multimer, and relationship to visceral adiposity. Endocrinology. 2009;150(7):3092-100. doi:10.1210/en.2008-1558.

16. Maddineni S, Metzger S, Ocon O, Hendricks 3rd G, Ramachandran R. Adiponectin gene is expressed in multiple tissues in the chicken: food deprivation influences adiponectin messenger ribonucleic acid expression. Endocrinology. 2005;146(10):4250-6. doi:10.1210/en.2005-0254.

17. Ocon-Grove OM, Krzysik-Walker SM, Maddineni SR, Hendricks 3rd GL, Ramachandran R. Adiponectin and its receptors are expressed in the chicken testis: influence of sexual maturation on testicular ADIPOR1 and ADIPOR2 mRNA abundance. Reproduction. 2008;136(5):627-38. doi:10.1530/REP-07-0446.

18. Chabrolle C, Tosca L, Crochet S, Tesseraud S, Dupont J. Expression of adiponectin and its receptors (AdipoR1 and AdipoR2) in chicken ovary: potential role in ovarian steroidogenesis. Domest Anim Endocrinol. 2007;33(4):480-7. doi:10.1016/j.domaniend.2006.08.002.

19. Krzysik-Walker SM, Ocon-Grove OM, Maddineni SR, Hendricks 3rd GL, Ramachandran R. Is visfatin an adipokine or myokine? Evidence for greater visfatin expression in skeletal muscle than visceral fat in chickens. Endocrinology. 2008;149(4):1543-50. doi:10.1210/en.2007-1301.

20. Li J, Meng F, Song C, Wang Y, Leung FC. Characterization of chicken visfatin gene: cDNA cloning, tissue distribution, and promoter analysis. Poult Sci. 2012;91(11):2885-94. doi:10.3382/ps.2012-02315.

21. Ons E, Gertler A, Buyse J, Lebihan-Duval E, Bordas A, Goddeeris B, et al. Visfatin gene expression in chickens is sex and tissue dependent. Domest Anim Endocrinol. 2010;38(2):63-74. doi:10.1016/j.domaniend.2009.08.007.

22. Diot M, Reverchon M, Ramé C, Baumard Y, Dupont J. Expression and effect of NAMPT (visfatin) on progesterone secretion in hen granulosa cells. Reproduction. 2015;150(1):53-63. doi:10.1530/REP-15-0021.

23. Coyral-Castel S, Rame C, Fatet A, Dupont J. Effects of unsaturated fatty acids on progesterone secretion and selected protein kinases in goat granulosa cells. Domest Anim Endocrinol. 2010;38(4):272-83. doi:10.1016/.domaniend.2009.12.002.

24. Reverchon M, Cornuau M, Rame C, Guerif F, Royere D, Dupont J. Chemerin inhibits IGF-1-induced progesterone and estradiol secretion in human granulosa cells. Hum Reprod. 2012;27(6):1790-800. doi:10.1093/humrep/des089.

25. Reverchon M, Cornuau M, Cloix L, Rame C, Guerif F, Royere D, et al. Visf is expressed in human granulosa cells: regulation by metformin through AMPK/SIRT1 pathways and its role in steroidogenesis. Mol Hum Reprod. 2013;19(5):313-26. doi:10.1093/molehr/gat002.

26. Chabrolle C, Tosca L, Rame C, Lecomte P, Royere D, Dupont J. Adiponectin increases insulin-like growth factor l-induced progesterone and estradiol secretion in human granulosa cells. Fertil Steril. 2009;92(6):1988-96. doi:10.1016/j.fertnstert.2008.09.008.

27. Chabrolle C, Tosca L, Dupont J. Regulation of adiponectin and its receptors in rat ovary by human chorionic gonadotrophin treatment and potential 
involvement of adiponectin in granulosa cell steroidogenesis. Reproduction. 2007;133(4):719-31. doi:10.1530/REP-06-0244.

28. Zabel BA, Allen SJ, Kulig P, Allen JA, Cichy J, Handel TM, et al. Chemerin activation by serine proteases of the coagulation, fibrinolytic, and inflammatory cascades. J Biol Chem. 2005;280(41):34661-6. doi:10.1074/jbc.M504868200.

29. Roh SG, Song SH, Choi KC, Katoh K, Wittamer V, Parmentier M, et al. Chemerin-a new adipokine that modulates adipogenesis via its own receptor. Biochem Biophys Res Commun. 2007;362(4):1013-8. doi:10.1016/j.bbrc.2007.08.104.

30. Docke S, Lock JF, Birkenfeld AL, Hoppe S, Lieske S, Rieger A, et al. Elevated hepatic chemerin mRNA expression in human non-alcoholic fatty liver disease. European journal of endocrinology / European Federation of Endocrine Societies. 2013;169(5):547-57. doi:10.1530/EJE-13-0112.

31. Kukla M, Zwirska-Korczala K, Hartleb M, Waluga M, Chwist A, Kajor M, et al. Serum chemerin and vaspin in non-alcoholic fatty liver disease. Scand J Gastroenterol. 2010;45(2):235-42. doi:10.3109/00365520903443852.

32. Yilmaz Y, Yonal O, Kurt R, Alahdab YO, Eren F, Ozdogan O, et al. Serum levels of omentin, chemerin and adipsin in patients with biopsy-proven nonalcoholic fatty liver disease. Scand I Gastroenterol. 2011;46(1):91-7. doi:10.3109/00365521.2010.516452.

33. Ernst MC, Issa M, Goralski KB, Sinal CJ. Chemerin exacerbates glucose intolerance in mouse models of obesity and diabetes. Endocrinology. 2010;151(5):1998-2007. doi:10.1210/en.2009-1098.

34. Yoshimura T, Oppenheim JJ. Chemokine-like receptor 1 (CMKLR1) and chemokine (C-C motif) receptor-like 2 (CCRL2); Two multifunctional receptors with unusual properties. Exp Cell Res. 2011;317(5):674-84.

35. Resnyk CW, Carre W, Wang X, Porter TE, Simon J, Le Bihan-Duval E, et al. Transcriptional analysis of abdominal fat in genetically fat and lean chickens reveals adipokines, lipogenic genes and a link between hemostasis and leanness. BMC Genomics. 2013;14:557. doi:10.1186/1471-2164-14-557.

36. Bozaoglu K, Bolton K, McMillan J, Zimmet P, Jowett J, Collier G, et al. Chemerin is a novel adipokine associated with obesity and metabolic syndrome. Endocrinology. 2007;148(10):4687-94. doi:10.1210/en.2007-0175.

37. Pasceri V, Yeh ET. A tale of two diseases Atherosclerosis and rheumatoid arthritis. Circulation. 1999;100(21):2124-6.

38. Wittamer V, Franssen JD, Vulcano M, Mirjolet JF, Le Poul E, Migeotte I, et al. Specific recruitment of antigen-presenting cells by chemerin, a novel processed ligand from human inflammatory fluids. J Exp Med. 2003:198(7):977-85. doi:10.1084/jem.20030382.

39. Parlee SD, Ernst MC, Muruganandan S, Sinal CJ, Goralski KB. Serum chemerin levels vary with time of day and are modified by obesity and tumor necrosis factor-\{alpha\}. Endocrinology. 2010;151(6):2590-602. doi:10.1210/en.2009-0794.

40. Zhao L, Yamaguchi Y, Sharif S, Du XY, Song JJ, Lee DM, et al. Chemerin158K protein is the dominant chemerin isoform in synovial and cerebrospinal fluids but not in plasma. J Biol Chem. 2011;286(45):39520-7. doi:10.1074/jbc.M111.258954.

41. Stejskal D, Karpisek M, Hanulova Z, Svestak M. Chemerin is an independent marker of the metabolic syndrome in a Caucasian population-a pilot study. Biomedical papers of the Medical Faculty of the University Palacky, Olomouc, Czechoslovakia. 2008;152(2):217-21.

42. Hansen IR, Jansson KM, Cannon B, Nedergaard J. Contrasting effects of cold acclimation versus obesogenic diets on chemerin gene expression in brown and brite adipose tissues. Biochim Biophys Acta. 2014;1841(12):1691-9. doi:10.1016/j.bbalip.2014.09.003.

43. Bozaoglu K, Curran JE, Stocker CJ, Zaibi MS, Segal D, Konstantopoulos N, et al. Chemerin, a novel adipokine in the regulation of angiogenesis. J Clin Endocrinol Metab. 2010;95(5):2476-85. doi:10.1210/jc.2010-0042.

44. Hu W, Feng P. Elevated serum chemerin concentrations are associated with renal dysfunction in type 2 diabetic patients. Diabetes Res Clin Pract. 2011;91(2):159-63. doi:10.1016/j.diabres.2010.11.016.

45. Jialal I, Devaraj S, Kaur H, Adams-Huet B, Bremer AA. Increased chemerin and decreased omentin-1 in both adipose tissue and plasma in nascent metabolic syndrome. J Clin Endocrinol Metab. 2013;98(3):E514-7. doi:10.1210/jc.2012-3673.

46. Sell H, Divoux A, Poitou C, Basdevant A, Bouillot JL, Bedossa P, et al. Chemerin correlates with markers for fatty liver in morbidly obese patients and strongly decreases after weight loss induced by bariatric surgery. J Clin Endocrinol Metab. 2010;95(6):2892-6. doi:10.1210/jc.2009-2374.
47. Tsao TS, Tomas E, Murrey HE, Hug C, Lee DH, Ruderman NB, et al. Role of disulfide bonds in Acrp30/adiponectin structure and signaling specificity. Different oligomers activate different signal transduction pathways. J Biol Chem. 2003;278(50):50810-7. doi:10.1074/jbc.M309469200.

48. Hara K, Horikoshi M, Yamauchi T, Yago H, Miyazaki O, Ebinuma H, et al. Measurement of the high-molecular weight form of adiponectin in plasma is useful for the prediction of insulin resistance and metabolic syndrome. Diabetes Care. 2006;29(6):1357-62. doi:10.2337/dc05-1801.

49. Tahmoorespur M, Ghazanfari S, Nobari K. Evaluation of adiponectin gene expression in the abdominal adipose tissue of broiler chickens: feed restriction, dietary energy, and protein influences adiponectin messenger ribonucleic acid expression. Poult Sci. 2010;89(10):2092-100 doi:10.3382/ps.2010-00772.

50. Yan J, Gan L, Chen D, Sun C. Adiponectin impairs chicken preadipocytes differentiation through p38 MAPK/ATF-2 and TOR/p70 S6 kinase pathways. PLoS One. 2013;8(10):e77716. doi:10.1371/journal.pone.0077716.

51. Izadi V, Farabad E, Azadbakht L. Epidemiologic evidence on serum adiponectin level and lipid profile. International journal of preventive medicine. 2013;4(2):133-40.

52. Pierre P, Froment P, Negre D, Rame C, Barateau V, Chabrolle C, et al. Role of adiponectin receptors, AdipoR1 and AdipoR2, in the steroidogenesis of the human granulosa tumor cell line, KGN. Hum Reprod. 2009;24(11):2890-901. doi:10.1093/humrep/dep292.

53. Hu Y, Ni Y, Ren L, Dai J, Zhao R. Leptin is involved in the effects of cysteamine on egg laying of hens, characteristics of eggs, and posthatch growth of broiler offspring. Poult Sci. 2008;87(9):1810-7. doi:10.3382/ps.2008-00040.

\section{Submit your next manuscript to BioMed Central and take full advantage of:}

- Convenient online submission

- Thorough peer review

- No space constraints or color figure charges

- Immediate publication on acceptance

- Inclusion in PubMed, CAS, Scopus and Google Scholar

- Research which is freely available for redistribution 